\title{
Implementasi Program Penugasan Dosen di Sekolah
}

\author{
Nana $^{1 *}$, Endang Surahman ${ }^{1}$, Irwan Muhammad Ridwan ${ }^{1}$ \\ 1Program Stud Pendidikan Fisika, Universitas Siliwangi, Tasikmalaya, Indonesia \\ *e-mail korespondensi: nana@unsil.ac.id
}

\begin{abstract}
Abstrak: Program Penugasan Dosen di sekolah merupakan salah satu Program Pengabdian kepada Masyarakat. Program ini secara umum bertujuan untuk meningkatkan relevansi antara LPTK dan SMA. Tujuan khusus program ini adalah untuk menyusun dan mengembangkan bahan ajar pendidikan Fisika berbasis karakter. Program ini dilaksanakan oleh 3 Dosen Fisika dari FKIP Pendidikan Fisika Universitas Siliwangi. Tempat pelaksanaan program ini adalah SMA Negeri 1 Ciamis sebagai sekolah laboratorium/mitra. Kegiatan yang dilaksanakan dalam program ini mencakup pengelolaan pembelajaran dan pendampingan dalam mengatasi permasalahan pembelajaran. Adapun pencapaian dalam program ini diwujudkan dengan tersusunnya silabus, RPP, dan bahan ajar Fisika berbasis karakter dan adanya pengembangan bahan ajar Fisika melalui penggunaan Model POE2WE.
\end{abstract}

Kata kunci: Bahan Ajar Berbasis Karakter, Program Penugasan Dosen Sekolah

\section{Pendahuluan}

Era perdangan bebas diterapkan secara bertahap mulai dari 2003-2020. Hal ini diungkapkan dalam kesepaktan APEC, AFTA, dan WTO (Tuwo, 2004). Perdagangan bebas ini memberikan dampak ganda antara terbukanya kesempatan kerjasama antar negara yang semakin luas dan timbulnya persingan yang semakin ketat. Oleh karena itu, perlu adanya peningkatan sumber daya manusia terkait daya saing dan keunggulan di semua sektor, terutama sektor pendidikan.

Sektor pendidikan merupakan sektor yang paling penting dalam hal peningkatan kualitas sumber daya manusia. Selain itu, pendidikan juga secara tidak langsung menjadi salah satu indikator pembangunan manusia (Badan Pusat Statistik, 2009). Semakin berpengetahuan sumber daya manusia suatu Negara, maka semakin tinggi indeks pembangunan manusianya. Lebih jauh, pendidikan merupakan kunci utama dalam kemajuan sebuah Negara. Dengan kualitas pendidikan yang baik maka sumber daya manusia sebuah Negara akan berkualitas serta akan secara otomatis berpengaruh terhadap perkembangan sebuah Negara.

Dengan perkembangan teknologi yang semakin pesat, sektor pendidikan dituntut untuk bisa menyesuaikan diri dengan perkembangan yang ada. Perkembangan teknologi pada dasarnya memberikan kemudahan sistem kerja. Peningkatan kemudahan sistem kerja ini harus dimanfaatkan dengan semaksimal mungkin oleh para akademisi dan praktisi pendidikan dengan melakukan pengembangan model-model pembelajaran berbasis teknologi yang lebih efektif dan efisien. Model-model pembelajaran berbasis teknologi yang sudah dikembangkan ini selanjutnya dapat dijadikan sebagai penunjang belajar yang komprehensif. Selain itu, proses pembelajaran dengan model pembelajaran berbasis teknologi juga dikembangkan menjadi lebih fleksibel, dapat dilaksanakan kapanpun dan dimanapun.

Sebagai Lembaga Pendidik Tenaga Kependidikan (LPTK) Universitas Siliwangi dituntut perannya melalui salah satu dari tridharmanya, yaitu Pengabdian 
kepada Masyarakat. Melihat data dan kenyataan tersebut, maka Tim Pelaksana Program Penugasan Dosen ke Sekolah, FKIP Unsil, bermaksud membantu memecahkan masalah tersebut. Program yang ditawarkan berupa penyusunan dan pengembangan Bahan Ajar Berbasis Karakter.

Sebagai Lembaga Pendidik Tenaga Kependidikan (LPTK), Universitas Siliwangi, memiliki peran tridharma untuk melakukan Pengabdian kepada Masyarakat. Pengabdian ini diwujudkan dalam bentuk Program Penugasan Dosen di Sekolah (Direktorat Pembelajaran, 2019). Program ini bertujuan untuk melaksanakan penyusunan dan pengembangan Bahan Ajar berbasis Karakter.

Penyusunan dan pengembangan bahan ajar berbasis karakter ini merupakan bentuk untuk mewujudkan kebijakan pendidikan yang diusung Presiden Joko Widodo dan Wakil Presiden Jusuf Kalla dalam Penguatan Pendidikan Karakter (PPK) (Kementerian Koordinator Bidang Pembangunan Manusia dan Kebudayaan, n.d.). Kebijakan PPK ini terintegrasi dalam Gerakan Nasional Revolusi Mental (GNRM) yaitu olah hati, olah raga, olah karsa, dan olah pikir. Nilainilai utama PPK adalah religiositas, nasionalisme, integritas, gotong royong, dan kemandirian. (Pusat Analisis dan Sinkronisasi Kebijakan, 2019).

Nilai-nilai

ini ingin ditanamkan dan dipraktikkan melalui sistem pendidikan nasional agar diketahui, dipahami, dan diterapkan di seluruh sendi kehidupan di sekolah dan di masyarakat. PPK lahir karena kesadaran akan tantangan ke depan yang semakin kompleks dan tidak pasti, namun sekaligus melihat ada banyak harapan bagi masa depan bangsa. Hal ini menuntut lembaga pendidikan untuk mempersiapkan peserta didik secara keilmuan dan kepribadian, berupa individu-individu yang kokoh dalam nilai-nilai moral, spiritual dan keilmuan. Memahami latar belakang, urgensi, dan konsep dasar PPK menjadi sangat penting bagi kepala sekolah agar dapat menerapkannya sesuai dengan konteks pendidikan di daerah masingmasing.

Pendidikan karakter adalah suatu sistem pendidikan yang bertujuan untuk menanamkan nilai-nilai karakter baik kepada peserta didik yang di dalamnya terdapat komponen pengetahuan tentang moral, perasaan tentang moral, dan perbuatan moral (Muslich, 2011). Pendidikan karakter memiliki konsep dasar tentang moral dimana tujuannya adalah untuk membentuk dan melatih kemampuan individu secara terusmenerus guna penyempurnaan diri kearah hidup yang lebih baik.

Berdasarkan penjelasan di atas, makalah ini bertujuan untuk menyusun dan mengembangkan Bahan Ajar berbasis karakter. Tujuan ini diwujudkan dalam bentuk implementasi Program Penugasan Dosen di Sekolah sebagai bentuk pengabdian kepada masyarakat.

\section{Metode Penelitian}

Pelaksana program PDS ini merupakan dosen-dosen yang terdaftar sebagai Dosen Program Studi Fisika, Universitas Siliwangi, diantaranya Dr. Nana, M.Pd, Dr. H Endang Surahman, M.Pd, dan Irwan Muhammad Ridwan, M.Pd. Berdasarkan hasil pengamatan dan evaluasi, LPTK mengusulkan untuk SMA Negeri 1 Ciamis dijadikan sebagai sekolah laboratorium dengan alasan sekolah tersebut merupakan sekolah pavorit dan merupakan sekolah yang input dan outputnya terbaik di priangan timur. Juga termasuk sekolah rujukan.

SMA Negeri 1 Ciamis memiliki jumlah rombongan belajar (rombel) sebanyak 34 rombel dengan masingmasing terdapat 2 jurusan kelas yaitu MIPA dan IPS. Untuk kelas XII terdapat 10 rombel dengan jumlah jurusan MIPA sebanyak 7 kelas dan jurusan IPS sebanyak 3 kelas. Kelas XI terdapat 12 rombel dengan jumlah jurusan MIPA sebanyak 7 kelas dan jurusan IPS sebanyak 5 kelas. Kelas X terdapat 12 rombel dengan jumlah jurusan MIPA 
sebanyak 7 kelas dan jurusan IPS sebanyak 5 kelas. Kapasitas setiap kelas seluruhnya kelas XII, XI, dan X berjumlah 36 siswa.

Dalam penelitian ini SMA Negeri 1 Ciamis dijadikan sebagai sekolah laboratorium dengan sarana dan prasarana yang sangat memadai terlebih pada laboratorium fisika. Laboratorium fisika SMA Negeri 1 Ciamis terletak di lantai satu, berada diantara kelas XI MIPA 4 dan Laboratorium komputer. Sarana dan prasaran yang terdapat di laboratorium fisika yaitu ruang laboratorium dan ruang persiapan alat.

Selain sarana dan prasarana, terdapat pula program kerja salah satunya pengadaan alat. Pengadaan alat ini bertujuan untuk mengganti alat-alat yang tidak layak pakai atau rusak, namun sebelumnya untuk menjalankan program kerja tersebut perlu adanya persetujuan dari kepala laboratorium yang kemudian disetujui oleh kepala sekolah.

\section{Hasil dan Pembahasan}

Kegiatan ini diawali pelaksanaan pembalajaran di SMA Negeri Ciamis. Pembelajaran Fisika SMA dikembangkan melalui Elaboration, Write and Evaluation (EWE) yang merupakan pengembangan dari Saintifik, Kurikulum 2013, POEW dan Kontruktivistik yang selanjutkanya dikembangkan menjadi model POE2WE. Setelah itu, kegiatan kemudian dilanjutkan dengan penyebaran kuesioner mengenai sikap peserta didik terhadap materi pembelajaran, sikap peserta didik terhadap proses pembelajaran, dan sikap peserta didik terhadap guru.

\section{Sikap Peserta Didik terhadap Materi Pembelajaran}

Berdasarkan kuesioner yang diberikan kepada peserta didik, berikut hasil perhitungan dari jawaban peserta didik dari penyataan-penyataan yang diajukan untuk mengetahui sikap peserta didik terhadap materi pembelajaran disajikan dalam Gambar 1.

Gambar 1 menunjukkan hasil perhitungan sikap peserta didik terhadap materi pembelajaran dapat dilihat dalam angka dan persentase sebagai berikut: siswa senang belajar fisika, karena materi dalam fisika sebagai salah satu mata pelajaran penunjang ke perguruan tinggi. Angka dan persentase responden terhadap pernyataan ini sebesar 154 atau $77 \%$ dengan kategori layak dan tidak perlu revisi.

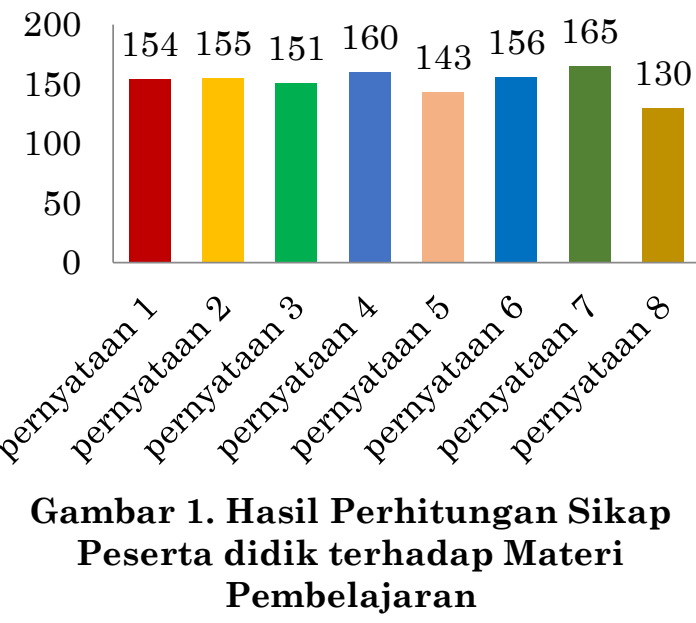

Selain itu siswa senang belajar masalah fisika, karena materi-materi di dalamnya dapat diterapkan dalam kehidupan sehari-hari. Angka dan persentase responden terhadap pernyataan ini sebesar 155 atau 77,5\% dengan kategori layak dan tidak perlu revisi. Siswa merasa termotivasi dalam mempelajari masalah fisika. Angka dan persentase responden terhadap pernyataan ini sebesar 151 atau 75,5\% dengan kategori layak dan tidak perlu revisi.

Siswa senang belajar fisika, karena masalah fisika yang siswa pelajari bersifat aktual (nyata) sesuai dengan permasalahan dalam kehidupan seharihari. Angka dan persentase responden terhadap pernyataan ini sebesar 160 atau 80\% dengan kategori sangat layak dan tidak perlu revisi. Siswa senang belajar fisika, karena dalam mempelajari fisika siswa menghubungkan dengan realitas kehidupan sehari-hari dan tidak sekedar membaca buku pelajaran fisika saja. Angka dan persentase responden terhadap pernyataan ini sebesar 143 atau $71,5 \%$ dengan kategori layak dan tidak perlu revisi. 
Siswa senang belajar fisika, karena hasil belajar siswa diukur dari aspek proses dan hasil belajar. Angka dan persentase responden terhadap pernyataan ini sebesar 156 atau 78\% dengan kategori layak dan tidak perlu revisi. Siswa senang belajar fisika, karena gambargambar statis yang disajikan dalam materi akan lebih mudah dalam memahami isi materi. Angka dan persentase responden terhadap pernyataan ini sebesar 165 atau 82,5\% dengan kategori sangat layak dan tidak perlu revisi. Contoh-contoh soal dalam materi fisika mudah siswa pahami. Angka dan persentase responden terhadap pernyataan ini sebesar 130 atau $65 \%$ dengan kategori kurang layak dan perlu revisi.

\section{Sikap Peserta Didik terhadap Proses Pembelajaran}

Selain itu, kuesioner juga diberikan kepada peserta didik untuk mengetahui sikap mereka terhadap proses pembelajaran yang dilaksanakan. Berikut hasil perhitungan dari jawaban peserta didik dari penyataan-penyataan yang diajukan untuk mengetahui sikap peserta didik terhadap proses pembelajaran disajikan dalam Gambar 2.

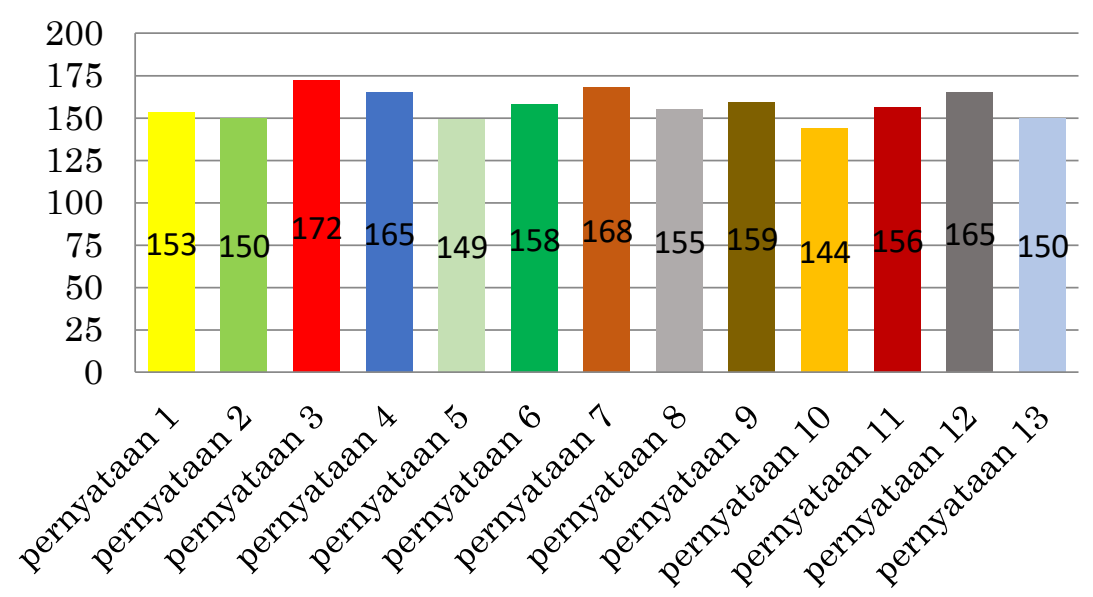

Gambar 2. Hasil Perhitungan Sikap Peserta Didik Terhadap Proses Pembelajaran

Gambar 2 menunjukkan hasil perhitungan sikap peserta didik terhadap proses pembelajaran dapat dilihat dalam angka dan persentase sebagai berikut: siswa senang mengikuti pembelajaran, karena diberi kesempatan untuk menyampaikan pendapat. Angka dan persentase responden terhadap pernyataan ini sebesar 153 atau 76,5\% dengan kategori layak dan tidak perlu revisi. Dalam mempelajari fisika, siswa senang membangun pengetahuan sendiri berdasarkan pengetahuan yang siswa miliki. Angka dan persentase responden terhadap pernyataan ini sebesar 152 atau $75 \%$ dengan kategori layak dan tidak perlu revisi.

Adanya kegiatan demontrasi/ praktikum dalam mempelajari masalah fisika, siswa akan lebih memahami materi fisika. Angka dan persentase responden terhadap pernyataan ini sebesar 172 atau 86\% dengan kategori sangat layak dan tidak perlu revisi. Dalam mempelajari fisika, siswa senang belajar secara kelompok, karena siswa dapat mendiskusikan permasalahan secara bersama-sama. Angka dan persentase responden terhadap pernyataan ini sebesar 165 atau 86\% dengan kategori sangat layak dan tidak perlu revisi.

Siswa senang mengikuti pembelajaran, karena metode yang dikembangkan lebih memahami konsepkonsep dalam fisika.. Angka dan persentase responden terhadap pernyataan ini sebesar 149 atau 74,5\% dengan kategori layak dan tidak perlu revisi. Siswa senang mempelajari fisika jika disampaikan dengan metode demonstrasi, diskusi dan tanya jawab. Angka dan persentase responden terhadap pernyataan 
ini sebesar 158 atau 79\% dengan kategori layak dan tidak perlu revisi.

Dengan metode demonstrasi/ praktikum mata pelajaran fisika akan mudah diingat dan dimengerti. Angka dan persentase responden terhadap pernyataan ini sebesar 168 atau 84\% dengan kategori sangat layak dan tidak perlu revisi.

Siswa senang mengikuti pembelajaran karena suasana pembelajaran yang dilaksanakan interaktif, inspiratif dan menyenangkan. Angka atau persentase responden terhadap pernyataan ini sebesar 155 atau $77,5 \%$ dengan kategori layak dan tidak perlu revisi.

Siswa senang mengikuti pembelajaran karena dalam pembelajaran disediakan kondisi yang dapat memfasilitasi belajar secara mandiri dan atau kelompok. Persentase responden terhadap pernyataan ini sebesar 159 atau 79,5\% dengan kategori layak dan tidak perlu revisi. Siswa senang mengikuti pembelajaran karena siswa diberikan kesempatan untuk mempresentasikan hasil belajar sesuai dengan hasil kegiatan yang telah siswa lakukan. Angka atau persentase responden terhadap pernyataan ini sebesar 144 atau 72,5\% dengan kategori layak dan tidak perlu revisi.

Siswa senang diberi kesempatan untuk melakukan evaluasi diri dan refleksi terhadap kegiatan yang telah siswa lakukan. Angka dan persentase responden terhadap pernyataan ini sebesar 156 atau 78\% dengan kategori layak dan tidak perlu revisi. Siswa senang mengikuti pembelajaran fisika karena diberi kesempatan melakukan percobaan dalam kegiatan praktikum. Angka dan persentase responden terhadap pernyataan ini sebesar 165 dan 82,5\% dengan kategori sangat layak dan tidak perlu revisi. Siswa senang mengikuti pembelajaran karena tugas-tugas sesuai dengan pembelajaran. Angka dan persentase responden terhadap pernyataan ini sebesar $75 \%$ dengan kategori layak dan tidak perlu revisi.

\section{Sikap Peserta Didik terhadap Guru}

Selain kuesioner sikap peserta didik terhadap materi dan proses pembelajaran, peserta didik juga diberikan kuesioner mengenai sikapnya terhadap guru. Berikut hasil perhitungan dari jawaban peserta didik dari penyataan-penyataan yang diajukan untuk mengetahui sikap peserta didik terhadap guru disajikan dalam Gambar 3.

Gambar 3 menunjukkan hasil perhitungan sikap peserta didik terhadap guru dapat dilihat dalam angka dan persentase sebagai berikut: guru sebagai fasilitator, guru menyediakan sarana dan situasi belajar agar siswa mampu mengkontruksi pengetahuan sendiri. Angka dan persentase responden terhadap pernyataan ini sebesar 172 atau $86 \%$ dengan kategori sangat layak dan tidak perlu revisi.

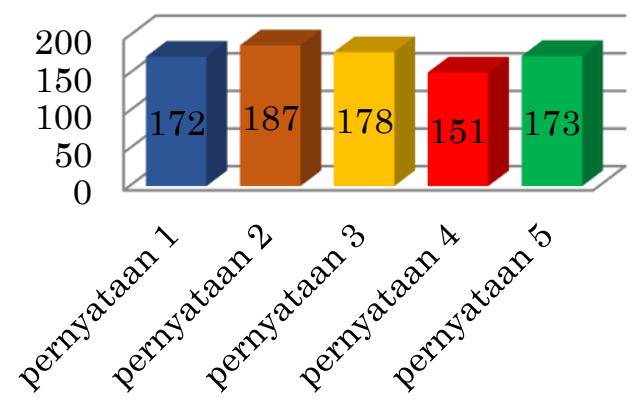

Gambar 3. Hasil Perhitungan Sikap Peserta didik terhadap Guru

Siswa senang jika guru selalu menghargai pendapat/ jawaban dari siswa. Angka dan persentase responden terhadap pernyataan ini sebesar 187 atau $86 \%$ dengan kategori sangat layak dan tidak perlu revisi. Siswa senang, jika guru memberi motivasi kepada siswa agar dapat mengajukan pertanyaan kepada siswa. Angka dan persentase responden terhadap pernyataan ini sebesar 178 atau $89 \%$ dengan kategori sangat layak dan tidak perlu revisi.

Siswa senang jika guru menugaskan siswa untuk mendiskusikan atau mencetuskan ide berdasarkan pertanyaan atau pernyataan. Angka dan persentase responden terhadap pernyataan ini sebesar 151 atau $75 \%$ dengan kategori layak dan 
tidak perlu revisi. Siswa suka dan cinta kepada guru. Angka dan persentase responden terhadap pernyataan ini sebesar 173 atau 86,5\% dengan kategori sangat layak dan tidak perlu revisi.

\section{Membantu Mengatasi Masalah Pembelajaran}

Berdasarkan hasil kuesioner mengenai sikap peserta didik terhadap materi pembelajaran, model pembelajaran, dan guru, selanjutnya dilakukan validasi mengenai penilaian model dan perankat pembelajaran yang digunakan. Adapun hasil penilaian oleh validator disajikan dalam Tabel 1.

Tabel 1: Hasil Penilaian Perangkat Pembelajaran oleh Validator

\begin{tabular}{cccccc}
\hline & \multicolumn{4}{c}{ Rata-rata Persentase Penilaian Oleh Validator } \\
\cline { 2 - 5 } $\begin{array}{c}\text { Perangkat } \\
\text { Pembelajaran }\end{array}$ & Ahli & Guru & $\begin{array}{c}\text { Peserta } \\
\text { didik }\end{array}$ & $\begin{array}{c}\text { Rata- } \\
\text { rata }\end{array}$ & Kesimpulan \\
\hline $\begin{array}{c}\text { Silabus dan RPP } \\
\text { (Rencana Pelaksanaan } \\
\text { Pembelajaran) }\end{array}$ & 93,79 & 92,14 & - & 92,9792 & Sangat Layak \\
\hline $\begin{array}{c}\text { Bahan Ajar } \\
\text { Lembar Kerja Siswa }\end{array}$ & 86,89 & 92,51 & 93,19 & 90,86 & Sangat Layak \\
\hline (LKS) & 88,54 & 90,11 & - & 89,33 & Sangat Layak \\
\hline
\end{tabular}

Hasil validasi ahli dalam Tabel 1 menunjukkan penilaian yang sangat baik. Sedangkan hasil validasi praktisi tentang diperoleh kategori sangat baik. Adapun saran dan masukkan yang diberikan para ahli berkaitan dengan penyusunan urutan daftar isi pada prototipe model pembelajaran POE2WE, alur penulisan, dan penambahan isi materi.

Adapun saran mengenai penambahan materi, para ahli merujuk pada pedoman penyusunan materi dengan memperhatikan kedalaman dan cakupan materi (Depdiknas, 2008). Keluasan materi menggambarkan seberapa banyak materimateri yang dimasukkan, sedangkan kedalaman materi menyangkut rincian konsep- konsep yang terkadang di dalamnya, yang harus dipelajari oleh siswa. Materi pembelajaran perlu diidentifikasi secara tepat agar pencapaian kompetensi siswa dapat diukur. Selain itu, dengan mengidentifikasi jenis-jenis materi yang akan diajarkan, guru akan mendapatkan ketepatan dalam pemilihan metode pembelajaran. Setelah penilaian dan masukan-masukan yang diberikan, validator menyimpulkan bahwa perangkat pembelajaran "Sangat layak".

\section{Evaluasi Pelaksanan dan Keberlanjutan Program}

Program Penugasan Dosen di SMA Negeri 1 Ciamis ini, telah mencapai hasil yang cukup memuaskan, diantaranya:

1. Tersusunnya Perangkat Pembelajaran berupa Silabus, RPP dan Bahan Ajar yang berkarakter.

2. Guru semakin termotivasi untuk mengembangkan Bahan Ajar menggunakan model POE2WE

3. Tim pelaksana mendapatkan pengalaman secara langsung dalam mengajar sebagai guru di SMA.

4. Terwujudnya rancangan pembelajaran yang inovatif di SMA.

5. Terciptanya saling tukar pengalaman antara tim pelaksana dan guru di SMA.

6. Suasana kependidikan di SMA telah dihayatinya oleh tim pelaksana.

7. Terjadinya kerjasama yang saling menguntungkan antara FKIP Universitas Siliwangi dan SMA Negeri 1 Ciamis.

Akan tetapi, pelaksanaan program penugasan dosen di sekolah ini juga dilaksanakan bukan tanpa mengalami kendala. Adapun kendala yang ditemukan dalam pelaksanaan program penugasan dosen ini adalah sebagai berikut: 
1. Kesulitan menyesuaikan antara jadwal pelajaran di SMAN 1 Ciamis dan jadwal kegiatan tim pelaksana di kampus Universitas Siliwangi.

2. Tingkat perkembangan siswa SMAN 1 Ciamis yang berbeda dibanding mahasiswa yang biasa dihadapi tim pelaksana.

Selain itu, analisis pelaksanaan pembelajaran berdasarkan model yang telah dikembangkan dan perbaikanperbaikan yang telah dilakukan dari hasil validasi dengan cara memberikan kuesioner kepada peserta didik berupa:

1. Sikap terhadap Guru

2. Sikap terhadap materi Pembelajaran

3. Sikap terhadap proses pembelajaran

\section{Penutup}

Penguatan Pendidikan Karakter (PPK) merupakan kebijakan pendidikan yang dicanangkan pemerintah. Penguatan ini telah diwujudkan dalam program penugasan dosen di sekolah. Program ini diwujudkan dengan produk dan pengembangan bahan ajar berbasis karakter dengan model POE2WE. Oleh karena itu, kami berharap kegiatan ini dapat meningkatkan relevansi antara LPTK, dan SMA, terlebih kedepannya dapat membantu guru dalam menyusun bahan ajar pendidikan fisika yang berbasis karakter serta dapat mengembangkan bahan ajar pendidikan fisika berbasis karakter.

\section{Referensi}

Badan Pusat Statistik. (2009). Indikator Pembangunan Manusia. Retrieved from Badan Pusat Statistik website: https://www.bps.go.id/subject/26/indek s-pembangunan-manusia.html

Depdiknas. (2008). Perangkat pembelajaran KTSP SMA. Jakarta: Direktorat Pembinaan Sekolah Menengah Atas.

Direktorat Pembelajaran. (2019). Panduan panduan bantuan penugasan dosen di sekolah (PDS).

https://doi.org/10.1017/CBO97811074

15324.004

Kementerian Koordinator Bidang

Pembangunan Manusia dan

Kebudayaan. (n.d.). Penguatan

pendidikan karakter untuk

menghadapi perkembangan zaman.

Retrieved from Gerakan Nasional

Revolusi Mental website:

https://revolusimental.go.id/pers/peng uatan-pendidikan-karakter-untukmenghadapi-perkembangan-zaman

Muslich, M. (2011). Pendidikan karakter. Jakarta: Bumi Aksara.

Pusat Analisis dan Sinkronisasi

Kebijakan. (2019). Penguatan

pendidikan karakter. Retrieved from

Kementerian Pendidikan dan

Kebudayaan website:

https://cerdasberkarakter.kemdikbud. go.id/?page_id=132

Tuwo, L. D. (2004). Kajian Visi Indonesia 2020. Info Kajian Bappenas, 1(1), 113. Retrieved from http://perpustakaan.bappenas.go.id/ lontar/opac/themes/bappenas4/temp lateDetail.jsp?id=81471\&lokasi=lok al. 